\title{
Chapter 11 \\ Tackling Indigenous Incarceration Through \\ Promoting Engagement with Higher \\ Education
}

\author{
Christopher Lee, Helen Farley, Jacinta Cox, and Stephen Seymour
}

\section{Introduction}

In Australia, nearly 39,000 people are in prison. But the more disturbing statistic is that Indigenous prisoners account for some $27 \%$ of the prison population, yet only $2 \%$ of the general population (Australian Bureau of Statistics 2016). Between 2000 and 2013, the imprisonment rate for Indigenous Australians increased by 57\%, while the rate for non-Indigenous Australians has remained relatively stable (Taillier 2015; Martin 2015). By the end of 2014, Indigenous Australians were twelve times more likely to be incarcerated than other Australians, and at the time of writing, the rate of imprisonment had risen an additional 6.3\% from the previous year (Australian Bureau of Statistics 2016).

Indigenous Australians are more likely than non-Indigenous people to experience higher and more frequent levels of contact with the criminal justice system, with shorter times between contacts (Allard 2010). They are almost twice as likely as non-Indigenous people to be charged with an offence more than once (Allard 2010). Those risk factors for offending that apply to the wider Australian population are just as applicable to the Indigenous population. These include being young, from a low socio-economic status background, unemployed, a substance user and with limited education (Hunter 2001; Weatherburn et al. 2006). However, data drawn from surveys such as the National Aboriginal and Torres Strait Islander Social Survey (NATSISS) have found Indigenous people experience additional risk factors arising from insecurity around cultural identity (Hampton and Toombs 2013). Although difficult to measure, these risk factors can be linked to historic dispossession, colonisation, disempowerment of elders and forcible child removal, and are believed to be significant contributors to social disorganisation. This is

C. Lee $\bullet$ H. Farley $(\bowtie) \bullet J$. Cox $\bullet$ S. Seymour

Digital Life Lab, University of Southern Queensland, Toowoomba, QLD, Australia

e-mail: christopher.lee@usq.edu.au; helen.farley@usq.edu.au; jacinta.cox@usq.edu.au;

Stephen.Seymour@usq.edu.au 
characterised by intergenerational cycles of substance abuse, neglect and violence within and between families (Allard 2010), impacting on the larger community and engendering feelings of hopelessness, helplessness, despair and rage (Memmott et al. 2001).

This chapter reports on a project led by researchers at the University of Southern Queensland (USQ), which aims to increase access to higher education for Indigenous prisoners. The project, which is currently active in 20 sites in Queensland, Western Australia, New South Wales and Tasmania, has developed digital technologies that don't require access to the internet and allow prisoner access to a series of university courses and programs. Prominent in these offerings is a pre-tertiary program, the Indigenous Higher Education Pathways Program (IHEPP), designed specifically to act as a bridge into higher education for Indigenous prisoners. The chapter concludes with an examination of some of the other offerings the university is considering to effectively support Indigenous students both while they are incarcerated and upon release from custody.

\section{Educational Attainment and Incarceration for Indigenous Australians}

The intergenerational effect of insecurity around cultural identity is strongly correlated with increased levels of incarceration (Allard 2010). This is evidenced by the fact that Indigenous children are three times more likely to be removed from their families if a parent was forcibly removed. Also, these people are twice as likely to manifest behavioural issues relating to alcohol and drug abuse than their peers who escaped this trauma (Allard 2010; Zubrick et al. 2005). These behavioural issues almost certainly bring these people into contact with the criminal justice system. The detention rates for Indigenous youth is a staggering 24 times that of nonIndigenous youth (Allard 2010; Dodson and Hunter 2006). The policies leading to the forcible removal of children and subsequent institutionalisation have severely damaged the parenting capacity of many Indigenous parents. Having ineffective parents has been identified as a very significant risk factor for offending, as it contributes to high levels of truancy among young Indigenous people, compounding the ongoing cycle of boredom and unemployment. Research suggests that poor school attendance could be responsible for as much as one third of the difference in educational attainment between Indigenous students as compared to other young Australians (Hancock et al. 2013).

It is acknowledged that educational attainment is correlated with personal and social wellbeing across a range of indicators such as health, employment, housing, and contact with the criminal justice and welfare systems (Levin 2009). People with higher levels of educational attainment are less likely to have been arrested in a fiveyear period than those with lower levels of education (Australian Bureau of Statistics 2015). Research also shows that rates of recidivism are reduced by as much as $30 \%$ 
among released offenders who, while incarcerated, obtained a post-secondary qualification (Callan and Gardner 2005). This is echoed in the 2013-2014 Custodial Inspector's Annual Report to the Western Australian Government, where it is stated that a key factor in reducing the risk of reoffending was educational attainment. The report goes on to say that prisoners who had completed only part of a secondary education, without pursuing further qualifications, were more likely to reoffend as compared to prisoners who had completed secondary schooling or a higher qualification (Morgan 2014).

Education is central to the economic, social and cultural development of an individual. An Indigenous adult who possesses a Bachelor's degree is over three times more likely to be able to secure full-time employment than another who has not finished year 10 (SCGRP 2009). It is reasonable to assume that participation in higher education may have a positive impact on Indigenous health outcomes, employment and productivity as it does with non-Indigenous people (Levin 2009). Access and support to engage with education is a crucial part of any wider strategy that seeks to address unemployment, financial stress, welfare dependence, housing challenges and health programs for Indigenous people, in particular for those who are incarcerated. Those agencies responsible for the supervision of prisoners need to ensure good access to vocational and higher educational opportunities, both while incarcerated and on release from custody (SCGRP 2009).

\section{Education in Prison: Learning 'the Hard Way'}

Correctional centres are challenging learning environments, even for the most committed student. By their very nature, they are stressful, noisy, disorientating and depressing environments (Torre and Fine 2005). Skyrocketing imprisonment rates have led to overcrowding in every Australian jurisdiction with the exception of Tasmania (Australian Government Productivity Commission 2015). This results in two or three prisoners sharing cells that are designed to house one person (Mackay 2015). This can be difficult for the prisoner who wants to study being distracted by his or her cellmate who wants to talk, listen to music or watch television. In addition, institutional 'norms' such as daily lockdowns, cell searches and head counts cause frequent disruptions (Hopkins and Farley 2015). Security restrictions, cultural constraints and inconsistent staffing may prevent students from accessing education centres, resources and support. The increasing privatisation of prisons comes with additional implications for students (Andrew 2007) who find themselves on strict working schedules without adequate study time (Hopkins 2015). Prisoners are moved between correctional centres or even released, often with little advance notice, further disrupting study.

Undoubtedly, the prison environment is not conducive to effective studying for any prisoner, but Indigenous students experience further challenges as compared to their non-Indigenous counterparts. Geographical separation from country, combined with lateral conflict inside correctional centres, may trigger complex issues 
for Indigenous prisoners that cannot readily be resolved. These issues are compounded by a lack of appropriately qualified and culturally sensitive staff (Miller 2007). Incarceration often leads to heightened Indigenous anger, leading to even greater levels of fear and frustration (Grant 2014). Research also suggests that many prospective Indigenous students are reluctant to enrol in studies due to low levels of literacy and numeracy, feeling shame when they can't do a task (Callan and Gardner 2005).

Across the board, incarcerated students are further disadvantaged by low levels of digital literacy skills. These skills are now considered essential in nearly all workplaces, and are increasingly important in daily life for banking, shopping, interacting with government departments and accessing services (Farley et al. 2015). Research exploring the digital divide has identified that even outside of correctional centres, Indigenous people are excluded from fully leveraging the benefits of the digital age. Data from the 2011 Australian Census confirm this, with figures showing $63 \%$ of Indigenous households having internet access, compared to $77 \%$ of non-Indigenous households (Australian Bureau of Statistics 2013). Though this figure is likely to have improved when measured in the 2016 census, the disparity between Indigenous and non-Indigenous households is likely to endure.

\section{Higher Education on the Inside}

Only $1.5 \%$ of the eligible Australian prison population is engaged in higher education, with conditions of eligibility differing markedly between jurisdictions (Australian Government Productivity Commission 2015). The numbers of incarcerated students undertaking a specified higher education program in a particular correctional centre are very small. This mostly precludes the economic feasibility of universities providing face-to-face tuition in correctional facilities. In addition, correctional facilities are frequently very remote from university campuses. This is frequently true of those correctional centres with a high proportion of Indigenous prisoners. For example, the prison population of Lotus Glen Correctional Centre in Far North Queensland is 70\% Indigenous (Queensland Corrective Services 2015). The closest university campus to this centre is the Cairns campus of James Cook University which is some 90 min drive away. The situation is even worse for some correctional centres in Western Australia and the Northern Territory that are even more remote from university campuses in metropolitan centres. In addition, educators are frequently wary of going 'behind the wire' at correctional centres either due to fears for their own safety and/or because of prejudice against prisoners ('they are in there for a reason') (Warner 1998). For these reasons, correctional jurisdictions have turned to distance education providers for the provision of higher education in correctional centres. Some universities have provided higher education specifically to Indigenous students in correctional centres. CQUniversity, through its Nulloo Yumbah Indigenous learning, spirituality and research centre, delivered its Tertiary Entry Program into the Capricornia Correctional Centre as well as supporting 
prisoner access to other CQUniversity programs. The University of New England's TRACKS Tertiary Preparation Program has been delivered widely into correctional centres in Queensland (Woodford Correctional Centre) and New South Wales (Behrendt et al. 2012).

Distance education has traditionally been used to engage prisoners in higher education, delivering resources to students who are unable to undertake traditional faceto-face education (Salane 2008). Until recently, formal education and training delivery to prisoners in these jurisdictions was provided in non-digital forms, using large volumes of printed copies of the course materials and learning support resources, sometimes supplemented by CDs for use on in-cell laptops in some jurisdictions or in computer labs (Dorman and Bull 2003). This is costly for universities to assemble, print and post, is in no way interactive, and cannot incorporate all of the learning support resources of the course. Incarcerated students often have very little or no contact with each other and are not able to leverage the social learning supports that are available to students engaged in online courses. This undermines the social constructive pedagogy favoured in many post-secondary programs and poorly prepares students for the world in which employers expect their employees to be familiar with social networking and other web 2.0 resources (Erisman and Contardo 2005). Furthermore, the traditional forms of delivery to incarcerated students do not enable them to develop the crucial graduate attributes promoted by most universities, including the digital literacies, collaborative teamwork and critical thinking skills required to complete studies in higher education and to obtain meaningful employment after release from custody.

These issues are hugely exacerbated by the fact that prisoners in most Australian jurisdictions are not permitted to access online learning technologies due to procedural restrictions prohibiting prisoner access to the internet (Farley and Doyle 2014). This becomes problematic as most universities shift to a predominantly online delivery of their courses and programs. For example, in Semester 12015 , USQ moved all of its courses and programs online and ceased production of hardcopy materials, including CD-ROMs. Though the university did slightly relent and still provides hard copy materials to incarcerated students enroled in the Tertiary Preparation Program, this is an interim measure. It is expected that these activities will not be funded beyond 2017 at the latest, and alternative methods of program delivery will need to be found or the provision of higher education into correctional centres will cease. In response to this urgent need, researchers began work on a series of projects to introduce digital technologies, which do not require access to the internet, into correctional centres to provide access to enabling and undergraduate programs. These projects will be described later in the chapter.

The University of Southern Queensland is the largest provider of higher education into correctional centres in Australia. It has been providing distance education into Australian prisons for some 25 years. The Tertiary Preparation Program, offered by USQ's Open Access College, was written specifically as a bridging program for incarcerated students and was later adapted for a broader (non-incarcerated) student cohort. At any one time, there are around 300 incarcerated students participating in the program (of about 900 enrolments). In addition, there are around 150 incarcerated 
students from around Australia enrolled in a range of undergraduate programs. Though exact numbers are not known, very few (thought to be less than 2\%) of these incarcerated students are Indigenous. This is thought to be because of the lower rates of educational attainment compared to non-Indigenous prisoners, because of the reluctance of Indigenous prisoners to engage with non-Indigenous prisoners to study (and vice versa), because of traumatic previous experiences with formal education, and because, to date, materials have not been culturally appropriate (Day 2003). USQ currently supports a large number of Indigenous students. Since 2009, Indigenous students have made up 1.6\% of USQ's enrolments (in comparison with the national average of $0.7 \%$ ). Incarcerated students make up some $1.3 \%$ of USQ's student population over the same period.

\section{Improving Access to Digital Higher Education in Correctional Centres}

The University of Southern Queensland's mission is 'To enable broad participation in higher education and to make significant contributions to research and community development' (USQ 2012), consistent with the recommendations of the Bradley Review of Higher Education (2008). The motto that USQ promulgates is Per studia mens nova - 'through study the mind is renewed' - and the university achieves this by making a significant contribution to the building of human and social capital through ensuring higher education is accessible to people regardless of their location and individual circumstances.

The first projects undertaken by the university to provide access to digital higher education did not have a specific focus on Indigenous prisoners. Though these students were encouraged to join the projects, participation by this group tended to be very low for reasons outlined previously. Each project built on the learnings of the previous project, ensuring that the outcomes of each were robust and repeatable before scaling up.

\section{Approach and Evaluation}

The projects were undertaken using a design-based research methodology which is a blend of empirical research and the theory-based design of learning environments (Design-based Research Collective 2003, p. 5). The method centres on the systematic investigation of innovations designed to improve educational practice through an iterative process of design, development, implementation and analysis in realworld settings (Wang and Hannafin 2005). A major strength of design-based research lies in its adaptability to adjust the intervention based on ongoing findings from participants. 
An independent formative and summative evaluation was undertaken by an external evaluator with expertise in project evaluation within educational contexts for each project. The evaluation was undertaken at the commencement of each project as well as at the conclusion of each project stage to provide an audit of project processes, progress towards intended outcomes, potential pitfalls and the quality of the outcomes achieved. For Making the Connection, in addition to an external evaluator who scrutinises project processes and evaluation, the project has an Indigenous evaluator, Professor Peter Radoll, who advises on strategies for engaging with Indigenous prisoners and external stakeholders. The team uses the evaluation feedback to inform the planning of consequent stages, thus improving the outcomes. Several sources of data are used including critical feedback from stakeholders, focus groups with the incarcerated students, and interviews with education officers. As a consequence of student enrolment, the university automatically collects data about enrolment, retention, progression and marks for each incarcerated student. Ethics approval was sought and granted to the various project teams by the University of Southern Queensland Ethics Committee and the research departments of the correctional jurisdictions in which the projects were/are operating.

\section{Portable Learning Environments for Incarcerated Adult Distance Education Students}

In early 2012, a pilot project titled Portable Learning Environments for Incarcerated Adult Distance Education Students (PLEIADES) sought to develop an internetindependent version of USQ's learning management system, a Moodle-based product called StudyDesk. The idea was to address the challenge of providing students with no internet access an equivalent learning experience to that of those students with connectivity. Early versions of the OffLine StudyDesk were trialled with incarcerated students at the Southern Queensland Correctional Centre (SQCC) in a joint initiative with Serco Asia Pacific (operators of SQCC) and Queensland Corrective Services (QCS).

Because prisoners had limited access to computer labs, they were also provided with eBook readers loaded with course readings in ePub format. These were used with one course from the university's Tertiary Preparation Program called TPP7120 Studying to Succeed. This pilot was trialled over Semesters 2 and 3 2012. This project was led by the university's Australian Digital Futures Institute (ADFI) with the Open Access College (OAC). The pilot was a proof of concept. Those incarcerated students responded favourably to the eBook readers and the OffLine StudyDesk. However, the project was prohibitively time intensive for both university and SQCC staff. To make this approach sustainable, the process of installing the OffLine StudyDesk had to be automated, at least to a certain extent. 


\section{From Access to Success}

From Access to Success: Improving the Higher Education Learning Experience for Students without Internet Access was an Australian Government Office for Learning and Teaching-funded project that built on the PLEIADES pilot and developed a level of automation to enable the OffLine StudyDesk to be deployed on the correctional centre education server through a series of DVDs and installed by the education officer. Again, the technology was trialled with TPP7120 Studying to Succeed but also deployed TPP7181 Mathematics Tertiary Preparation Program Level A at SQCC and the Maryborough Correctional Centre (MCC). This was significant as this project demonstrated that the OffLine StudyDesk could work in a publicly run correctional centre. This project built on the partnership between ADFI, OAC, QCS and Serco Asia Pacific and ran until June 2015. Again, student responses to the technology were positive.

\section{The Triple 'E' Project (Empowerment, E-Learning and E-Readers)}

This project began in Semester 1, 2013, and also built on the PLEIADES project. The project deployed eBook readers at three additional correctional centres beyond SQCC and MCC. The correctional centres were chosen on the basis of the number of students enrolled in TPP7120 Studying to Succeed and strong relationships between USQ TPP staff with the correctional centre education staff. The additional correctional centres were Brisbane Women's Correctional Centre, Wolston Correctional Centre and Woodford Correctional Centre. The three additional centres are directly administered by QCS. This project was led by OAC with ADFI, QCS and Serco Asia Pacific. The eBook readers were of a different model to those used in PLEIADES and were found to be unreliable, causing significant frustration to both education officers and students. The project was prematurely brought to a close so as not to disadvantage those students using the eBook readers. They were provided with hardcopy materials instead. Those students at SQCC and MCC also used the OffLine StudyDesk in the centre computer labs.

\section{Sorting Out University Processes}

To that point, the focus had been to provide technologies to correctional centres to improve access to digital higher education for prisoners. It was also recognised that there were some barriers at the university that made studying difficult for incarcerated students. Two projects funded by the Commonwealth government sought to improve university processes to better support incarcerated students. These projects, 
Paper to Pixels (2014) and Bridging the Digital Divide (2015), realigned university incarcerated student support processes to be more efficient, but also allowed the university to benchmark itself against other Australian universities in regard to the provision of higher education to incarcerated students and other students with unreliable internet access.

\section{Making the Connection}

In the latter half of 2013, the University of Southern Queensland was awarded \$4.39 million over 3 years by the Australian Government under the Higher Education Participation and Partnerships Program for a project titled Making the Connection: Improving Access to Higher Education for Low Socio-Economic Status Students with ICT Limitations. Beginning in early 2014, the project built on those previous projects led by the university which trialled digital technologies for learning in correctional centres.

Making the Connection builds on From Access to Success by continuing to develop the Offline StudyDesk so that it is robust, repeatable and reliable. One of the findings from the earlier project was that incarcerated students had only a few hours a week to access the correctional centre computer labs. This was because of the competition from other courses and programs, including vocational programs, for space and because students were typically employed in jobs in 'industries' within the correctional centre, restricting the time available to study. To help overcome these difficulties in access, the Making the Connection project will be providing notebook computers to participating students so they can take them back to their cells and continue working in their personal time.

\section{The Technologies}

A team comprising university ICT Services and Making the Connection personnel determined that the preferred solution remained to install the Offline StudyDesk on a separate server linked to the education lab network via a network switch. In the online environment, the StudyDesk works with a Learning Objects Repository (LOR) which holds course content. Course content is vetted for copyright status and tagged with metadata to make it searchable. When a student accesses a resource via the StudyDesk, they are actually accessing that resource through the Learning Objects Repository. This is obviously not feasible for those students using the Offline StudyDesk. To address this issue, a bespoke piece of software called a 'compiler' automatically harvests objects housed in the LOR, and packages the resources with the course for export to the correctional centre. Another piece of software called a 'checker' goes through each course to ensure that files within each course are functional and that links to the internet have been removed. 
At the moment, the transfer of courses between the university and correctional centres occurs via DVD. In the near future, education officers will be able to download courses through a kiosk hosted at USQ and accessed via the administrative network (which is internet-enabled). The version of the Offline StudyDesk is approximately one version behind the main production version to allow for any glitches to be ironed out.

Because incarcerated students have limited access to the computer labs, it was decided that it would be desirable for students to have a personal device that they could take back to their cells. As with the modified learning management system, these devices cannot be used to access the internet. Focus groups with incarcerated students participating in eBook reader trials in a previous project were critical of the small screen size and onscreen keyboard in these devices. Taking this feedback on board, the project team conducted a detailed options analysis of some 32 tablet computers, laptops and notebooks. It was decided that a Windows notebook would be most suitable as it had an almost full-size keyboard and adequate processing power and screen real estate would not be compromised by an onscreen keyboard. Also, students would be able to use LibreOffice to complete assessments. The project team have managed to make the Offline StudyDesk stable and reliable on the devices which are currently undergoing security certification in some jurisdictions.

Developing appropriate technologies is only part of the challenge of providing higher education to incarcerated students. Appropriate courses and programs had to be adapted for use with the technologies and use without access to the internet. Taking into account the levels of previous academic achievement in the correctional centres and jurisdictional sensitivities around students accruing Higher Education Contribution Scheme (HECS) debt, there is a focus on the courses of the Tertiary Preparation Program and Indigenous Higher Education Pathways Program, both Commonwealth-funded enabling programs that are supplemented by three diploma programs: the Diploma of Arts (Social Sciences), Diploma of Science (Environment and Sustainability) and Diploma of Business Administration.

Developing offline technologies is only part of the challenge of providing higher education to incarcerated students. Courses and programs have to be modified to function well in the offline context. A number of factors were taken into consideration when choosing programs for modification. The primary consideration was the likely previous academic achievements and experiences of the students. Many incarcerated students are from low socio-economic status backgrounds where lower academic achievement is more common. Similarly, low levels of education remain a key part of the ongoing cycle that leads to the overrepresentation of Indigenous people in the criminal justice system (Weatherburn et al. 2006). As USQ has been providing education to incarcerated students for around 25 years, the project team could access a large amount of data around the programs incarcerated students have typically enrolled in. Sentence length was an important consideration, especially given that around $90 \%$ of prisoners are incarcerated for one year or less. The project team also consulted with careers advisors at the university about the careers in which ex-offenders could reasonably expect to be employed, given that they will have a criminal record, and what programs would prepare them for those careers. 
The project team consulted with university course examiners (course coordinators), heads of school and executive deans about what courses could reasonably be adapted for delivery in the correctional environment; for example, courses with significant practical or residential components may be unsuitable. It was also established that it would be more beneficial to offer a selection of courses across a range of disciplines, rather than concentrate course modification efforts around one discipline as would be necessary with a degree program.

Jurisdictional administrators expressed concern about the potential for incarcerated students to acquire a significant HECS debt. They worked closely with the project team to ensure that HECS debts would be kept to a minimum and provide the best outcomes for prisoners. Taking into account the levels of previous academic achievement in the correctional centres and jurisdictional sensitivities around students accruing HECS debt, there was also a focus on the enabling or bridging courses, specifically the Tertiary Preparation Program and the Indigenous Higher Education Pathways Program, both of which are Commonwealth-funded enabling programs. These programs articulate into a number of undergraduate programs at USQ. In correctional centres, they articulate into three diploma programs: Diploma of Arts (Social Sciences), Diploma of Science (Environment and Sustainability) and Diploma of Business Administration. Diploma programs were selected in acknowledgement of the typically short sentence length of most prisoners.

The Indigenous Higher Education Pathways Program is of particular importance to this project given the overrepresentation of Indigenous Australians in correctional centres. The program has run for a number of years at the university out of the unit now called the Centre for Indigenous Studies, Education and Research (formerly the Centre for Australian Indigenous Knowledges). A key feature of this program has been a residential school at the beginning of the semester where students can meet their lecturers and each other before returning home to continue their studies, and students who are not incarcerated still participate in that residential school. As part of the Making the Connection project, the program has been developed for online and offline delivery. To make up for the fact that incarcerated students cannot attend the residential school, the program has been designed to incorporate a large amount of multimedia materials and interactivity. So far three courses have been redeveloped for deployment on the offline technologies. These are: ISE7001 Talking the Talk: Claiming your Voice within Academia; ISE7002 Learning the Lingo: Academic Writing; and ISE7003 Keeping on Track: Study Skills. Three more courses will be developed for delivery in Semester 2 2016. These will be ISE7004 Mathematics, as Storytelling; ISE7005 Walking the Walk: Applying Academic Skills; and ISE7006 Academic Conventions and Indigenous Research Methodologies. 


\section{Providing a Pathway}

The Indigenous Higher Education Advisory Council (IHEAC) advised that increasing Indigenous participation in higher education is one of the crucial factors in reducing Indigenous disadvantage. In line with IHEAC's Priority 1 which advocates universities working with Technical and Further Education (TAFE) providers, the project team originally brokered a partnership between Bendigo TAFE and USQ to coordinate activity and 'build pathways and raise levels of aspiration and confidence of Indigenous students' (IHEAC 2006). This approach was also recommended by Pechenkina and Anderson (2011, p. 12), who advocated:

the formulation of 'pipeline' programmes, which increase the pool of tertiary ready Indigenous students and transition programmes which provide academic development of enhancement for Indigenous tertiary students in order to ensure their successful completion.

This project provides a 'pipeline' by providing viable pathways into higher education for incarcerated students who are likely to be from low socio-economic status backgrounds (Pechenkina and Anderson 2011). Provision of access to these sorts of pathways is often sufficient for students from low socio-economic backgrounds, and once enrolled they frequently perform as well as their peers. Non-Indigenous incarcerated students will enter the pathway through the university's Tertiary Preparation Program. Indigenous incarcerated students may need additional pretertiary preparation, and hence originally it was envisioned that there would be additional entry points into this higher education pathway through Bendigo TAFE (now Bendigo Kangan Institute) Certificates I, II and III in Mumgu-dhal tyama-tiyt, before articulating into the university's Indigenous Higher Education Pathways Program (CSHE 2008). Behrendt et al. (2012) acknowledged the difficulties in providing education for Indigenous incarcerated students. They also acknowledged the societal and individual benefits to be gained by persevering. Unfortunately, due to uncertainty around delivery and funding in the vocational sector, the project team had to reluctantly delay the incorporation of additional vocational entry points into the pipeline into higher education for Indigenous incarcerated students. However, in the course of talking to Indigenous prisoners and correctional jurisdictions, the team has become even more convinced that these additional entry points are important and are talking with potential partners in multiple jurisdictions to this end.

\section{Engagement with Indigenous Incarcerated Students}

A major part of the project is focused on student engagement and outreach where two engagement coordinators liaise directly with students, where appropriate, to encourage them to participate in the project. The project has employed an Indigenous Engagement Coordinator who is Indigenous to talk directly to Indigenous prisoners. A former correctional officer himself, he visits in scope correctional centres and 
talks to Indigenous prisoners about a range of issues including education. The engagement coordinator builds relationships with the Indigenous prisoners over time, gaining their trust and learning about each prisoner's particular circumstances. At an appropriate time, he talks to them about engaging with the project. Sometimes it is not appropriate that they work with the project and he may direct them to numeracy and literacy classes or other programs instead. The project is careful to guard against setting Indigenous students up to fail, especially as they often already have low levels of self-esteem due to previous traumatic experiences with formal education.

While the authors acknowledge that there are a number of disciplinary and individual viewpoints when considering Indigenous ways of learning, it is beyond the scope of this work to revisit these controversies. A fuller description can be read in the work of Donovan (2006) and Yunkaporta (2009). Even so, some current research suggests that Indigenous ways of learning may align with what the university's StudyDesk environment offers (Donovan 2006; Duggan 2009). For example, the platform allows for culturally relevant and complex imagery or materials that align with traditional Indigenous learning techniques to be embedded in courses. Although none suggest that these approaches are the only way in which an Indigenous person can learn, this approach reinforces a strong foundation in holistic (global) learning which includes visual/spatial skills, and contextual and spontaneous learning (Duggan 2009).

The Indigenous Community Engagement Coordinator has developed a culturally appropriate and sensitive Indigenous incarcerated student engagement strategy that acknowledges recognised Indigenous pedagogies. For the sake of harmony, practicality, expedience and simplicity, the various assertions and models of Aboriginal pedagogy in the corpus may be reorganised into eight accessible orientations, (1) deconstruct/reconstruct, (2) learning maps, (3) community links, (4) symbols and images, (5) non-verbal, (6) land links, (7) story sharing and (8) non-linear methodologies, to inform the Making the Connection project's Indigenous incarcerated student engagement strategy (Yunkaporta 2009).

Indigenous cultures are acknowledged as oral cultures where information and knowledge were handed down through song, ceremony, dance and images. As oral traditions still continue in many communities, the project's approach to engaging with Indigenous incarcerated students' needs to accommodate these protocols. This is especially true in correctional centres where the stories may not be creation stories but are nonetheless stories which have been handed down. Indigenous people use language which is a combination of Aboriginal English, Creole, slang and swearing. Formal English is very often not the first language for many Indigenous prisoners (Malcolm and Königsberg 2007). The formal English language of higher education can itself be a barrier to participation in higher education for Indigenous prisoners (Miller 2007).

The Indigenous Community Engagement Coordinator is developing the story of the USQ Offline StudyDesk initiative and will work closely with education officers and cultural liaison officers in all scope centres but particularly Wolston Correctional Centre, Brisbane Women's Correctional Centre and the Southern Queensland 
Correctional Centre at Gatton to engage with Indigenous prisoners. The project is working on triggering motivations for incarcerated students to engage with education and break the cycle of reoffending and re-incarceration. As the project has a limited time frame, developing the necessary relationships with incarcerated students will require establishing connections through existing relationships including the education officers and cultural liaison officers at each correctional centre. The Indigenous community engagement coordinator is working closely with the College for Indigenous Studies, Education and Research at USQ to prepare the new version of the IHEPP to be accessed through the Offline StudyDesk initiative.

\section{Results}

The project team conducts focus groups with participating students as often as possible, which is difficult given that students are now spread out across the country. Focus groups are assembled opportunistically when project team members visit a correctional centre to deploy technologies or onboard new education staff. Focus group members are usually participants in the project but in some instances are prisoners considering joining the project. Not all participants joined the focus groups. Often conflicting work schedules or lockdowns prevented their participation. Generally speaking, prisoners are usually over 28 years of age. Education officers report that younger prisoners are generally not ready to undertake study. Both male and female prisoners have participated in focus groups. Initially, detailed notes were taken as it was very difficult to bring electronic recording devices into correctional centres. More recently, these restrictions have been relaxed and a small digital recorder is used to record discussions. These discussions are then transcribed using a professional transcription agency. Though interview guides were written and used, focus group participants tended to drive the discussions to also cover topics they were interested in. These discussions frequently centred around course materials and assessments. Discussion guides were intended to elicit responses around the ease of use of technologies, the nature of the correctional learning environment, challenges encountered by students trying to study, and previous experiences around study and technology.

To date, there have been some 622 enrolments across 20 sites in four states. Even so, the numbers of Indigenous students that have participated remain small. This is primarily because the Indigenous Higher Education Pathways Program courses have only been available since the beginning of the current semester. It is expected that the numbers of this cohort enrolled in the project will significantly increase from now on. In addition, the Indigenous Community Engagement Coordinator has only been employed with the project for some 5 months. One of the things that has become apparent during the course of the project is that courseware must also be supplemented with additional cultural materials for Indigenous prisoners. Even though cultural liaison officers do the best they can with limited resources, this is an area that has seen repeated funding cuts in response to the rising costs associated 
with increasing rates of incarceration and overcrowding. The project team is considering a crowdfunding campaign in order to buy cultural resources that can be placed in the correctional centre library or electronic versions placed on the Making the Connection offline technologies.

During the planning of the project, it was expected that the digital literacy of students would be low. To overcome this potential issue, the project team ensures that the education officers and IT support staff are trained in the use of the technologies. These staff, in turn, would support the students in the use of the project technologies. The prior levels of experience of the students with computers and mobile devices was mixed, with some students (usually those who had been in prison for a shorter period of time) being more familiar with the technologies than others. This was evidenced by the following pre-deployment focus group responses:

Facilitator: Have any of you used a smart phone before?

Student A: I played around with one before. I used an iPhone before I came in here; it was a piece of crap. I messed around with it, but didn't actually use it.

Student B: I've never even seen a mobile phone other than on TV.

Facilitator: You've never seen a mobile phone?

Student B: Nope, only on TV.

Student C: For a lot that are studying here, technology hasn't been around for them for say the last five to ten years, they haven't done any sort of training at all.

The variability in the digital literacies of students as well as staff had the potential to impact extensively on the effectiveness of the project. Students may not make effective use of the technologies as a result of lack of knowledge about how they worked and education officers were often not aware of the necessary features to assist students effectively in spite of training by project team members. The project team have tried to overcome this by bringing education officers to USQ for specific training around the use of the technologies (as well as around university processes and support). In addition, the project team are in frequent telephone contact with the education officers and try to troubleshoot issues as they arise. There is also a dedicated number that education officers can phone if issues arise.

Before the Making the Connection project, education officers or their equivalents had to download and print materials where possible for pre-tertiary and undergraduate students. Education officers primarily have an administrative role and generally are not able to offer tutorial support to students. Though the Making the Connection project is unable to provide tutorial support for students, it is believed that the availability of multimedia materials and interactive activities will promote engagement of students with the programs offered. Students have been largely positive about the project, technologies and programs offered. Access to education can change students in ways beyond making them more employable. Here are some testimonials from incarcerated students. These responses show the diversity of motivations that prisoners have to engage in study. Many become almost evangelical about the benefits of study. 
Student A: It's interesting that they treat education different to the core programs, when in fact it is the best form of rehabilitation. You are not going to change your person from some silly little six-month course ... educate a person and give them the skills they need to have a legitimate, successful employment status. If you don't give them the tools they need, they are going to go nowhere. They definitely should be pushing the education flagship much, much further.

Student B: I found it as an opportunity to redeem myself with my education. I really enjoy learning again. I was involved with drugs for a while but now my mind is clear. I really enjoy learning again.

Student C: Having my kids see me and see me move on to a career - so my kids can see I am going to turn my life around. Hopefully, I can turn things around because I don't want them thinking it's fine to come to jail because it's not.

Student D: I have been institutionalised my whole life. And I have another life sentence yet to do. I'm starting to think that I can help younger kids to not do the same mistakes that I did. Do courses, and get out and stay out. That's my main motivation, is helping the younger generation and the youth in detention.

Student E: I want to advance myself before I go home. You've got big time to fill. Finishing with a degree. It gives your friends and family something positive to say about you.

Student F: I thoroughly enjoyed studying through USQ, as it made a horrendous experience much more worthwhile. I look forward to completing my degree and hope more incarcerated students have the opportunity to excel.

Short surveys are also distributed to participants of the project yet return rates remain relatively low. This is associated with the time pressures experienced by education officers making it difficult to both distribute and collect the surveys. The surveys are short, with just a few questions focused on the experience of using the technologies for learning. Most responses consist of just a few words: 'It was easy' or 'No problems' are typical responses. An open-ended question, 'What would you like your course examiner to know?' elicited responses mostly around the conditions under which students were trying to study. 'Studying in here is hard' and 'We need extra time to do assignments' are typical responses. Though there is very little in the way of meaningful qualitative data elicited this way, most respondents indicate that they enjoy using the technology and find it reasonably easy to use.

As the project expands to more correctional centres in more jurisdictions and as the IHEPP courses become available to incarcerated students, it is expected that the participation of Indigenous students will dramatically increase. Through the interactions between potential students and the Indigenous Community Engagement Coordinator, there is already a piqued interest not only in the Making the Connection project programs but also in the other numeracy and literacy and vocational programs available in correctional centres. 


\section{Where to from Here?}

The Making the Connection project team have been very aware of the dangers of unreasonably raising the expectations of Indigenous prisoners only to let them down at the end of the project. The project team is working with senior management at the university to ensure that the technologies and programs developed as part of the project become part of mainstream offerings so that they are available beyond the life of the project. The development of the technologies and the redevelopment of the programs were completed by university staff seconded from their substantial area to the project, or paid for by the project, so that the expertise does not leave the institution at the end of the project at the end of 2016. This will ensure that the expertise to maintain the technologies and ensure that the offline courses are kept up-to-date will reside at the institution. The project team hope to augment these course offerings with additional entry points into the pathway through vocational education providers. Discussions with potential providers are underway.

Jurisdictional administrators have expressed a need for even shorter courses and programs to be offered to prisoners with very short sentences. To this end, the team is working with the Open University in the UK to make a selection of their badged Open Learn courses available in the offline environment. These courses cover a staggering array of topics from study guides to disciplinary introductions. The courses have been developed in Moodle and should require very little modification to be delivered via the OffLine StudyDesk accessed through the computer lab or the personal devices. These courses could provide a gentle introduction to learning for those students who lack the confidence or commitment to undertake a formal qualification.

An exciting possibility lies in making these technologies available for all those students without reliable internet access throughout Australia and the world. For example, broadband internet penetration is restricted in most countries within Southeast Asia due to poor infrastructure. This is mostly attributable to a lack of private investment coupled with the severely limited capacity of the people to pay for services (Jeroschewski et al. 2013). The technologies and programs developed as part of the Making the Connection project have the potential to make higher education accessible to those unable to travel to a large city to study face-to-face, allowing people to remain in their communities and support the economic and social development of their regions. The issues facing incarcerated Indigenous prisoners are very similar to the issues faced by incarcerated Indigenous peoples all around the world. The project team has undertaken the first tentative steps in talking to the educators tasked with providing education to those people with a view to sharing both the technologies and the considerable learnings from the project to date.

This chapter has introduced the startling and disheartening realities surrounding the overrepresentation of Indigenous people in the Australian criminal justice system. It has outlined a series of projects undertaken by researchers at the University of Southern Queensland, culminating in the Australian government-funded Making the Connection project. This project has a particular focus on providing a pathway 
into higher education for Indigenous prisoners with a view to reducing reoffending rates and recidivism so that those people can remain in their communities, imagining an alternative future for themselves and for their families. In this way it would be possible to reduce the rates of Indigenous incarceration. The overrepresentation of Indigenous people in Australian prisons remains one of Australia's greatest and most shameful tragedies.

\section{References}

Allard, T. (2010). Understanding and preventing indigenous offending. Research Briefs (9). Sydney: Indigenous Justice Clearinghouse.

Andrew, J. (2007). Prisons, the profit motive and other challenges to accountability. Critical Perspectives on Accounting, 18(8), 877-904.

Australian Bureau of Statistics. (2013). Households with internet access. Retrieved from: http:// www.abs.gov.au/ausstats/abs@.nsf/Lookup/2076.0main+features702011

Australian Bureau of Statistics. (2015). 4512.0 - Corrective Services, Australia, March Quarter 2015. Retrieved from Canberra, Australia: http://www.abs.gov.au/ausstats/abs@.nsf/mf/4512.0

Australian Bureau of Statistics. (2016). Summary of findings: Persons in corrective services. Retrieved from: http://www.abs.gov.au/ausstats/abs@.nsf/Lookup/bySubject/4517.0 2016 MainFeatures Keyfindings 1

Australian Government Productivity Commission. (2015). Justice. In P. Harris (Ed.), Report on government services (Vol. C). Canberra: Productivity Commission.

Behrendt, L., Larkin, S., Griew, R., \& Kelly, P. (2012). Review of higher education access and outcomes for Aboriginal and Torres Strait Islander people: Final report. Canberra: Department of Industry, Innovation, Science, Research and Tertiary Education.

Bradley, D., Noonan, P., Nugent, H., \& Scales, B. (2008). Review of Australian higher education, final report. Canberra: Commonwealth of Australia.

Callan, V., \& Gardner, J. (2005). Vocational education and training provision and recidivism in Queensland correctional institutions. Adelaide: NCVER.

CSHE (2008). Participation and equity. A review of the participation in higher education of people from low socioeconomic backgrounds and Indigenous people. University of Melbourne: Centre for the Study of Higher Education.

Day, A. (2003). Reducing the risk of Re-offending in Australian indigenous offenders: What works for whom? Journal of Offender Rehabilitation, 37(2), 1-15. doi:10.1300/J076v37n02_01.

Design-Based_Research_Collective. (2003). Design-based research: An emerging paradigm for educational inquiry. Educational Researcher, 32(1), 5-8.

Dodson, M., \& Hunter, B. (2006). Selected crime and justice issues for indigenous families. Family Matters, 75, 34-41.

Dorman, M. \& Bull, D. (2003). Aligning educational needs with institutional priorities: Facilitating offender reintegration into contemporary society. IFECSA conference. Retrieved from www. acea.org.au/.../2003papers/PaperDorman_Bull.pdf

Donovan, M. (2006). Can information communication technological tools be used to suit aboriginal learning pedagogies? In L. E. Dyson, M. Hendriks, \& S. Grant (Eds.), Information technology and indigenous people (pp. 93-104). Hershey: Information Science Publishing.

Duggan, T. (2009). Supporting ways of learning for Indigenous Australian pre-undergraduate students using Moodle. In Same places, different spaces. Proceedings ascilite Auckland 2009. http://www.ascilite.org.au/conferences/auckland09/procs/duggan.pdf

Dyson, L. E., Hendriks, M., \& Grant, S. (Eds.). (2006). Information technology and indigenous people. Hershey: Information Science Publishing. 
Erisman, W., \& Contardo, J. (2005). Learning to reduce recidivism: A 50-state analysis of postsecondary correctional education policy. Washington, DC: The Institute for Higher Education Policy.

Farley, H., \& Doyle, J. (2014). Using digital technologies to implement distance education for incarcerated students: A case study from an Australian regional university. Open Praxis, 6(4), 357-363.

Farley, H., Pike, A., Hopkins, S., \& Byrne, C. (2015). Bringing digital literacies to students in prison: Challenges and opportunities. Paper presented at the Unlocking Innovation in Education in Prison: EPEA 2015 Conference, Antwerp, Belgium. http://www.epea.org/wp/wpcontent/uploads/EPEA-Conference-programme-book.pdf

Grant, E. M. (2014). Prisons for Aboriginal and Torres Strait Islander People: meeting physical and mental health needs. Paper presented at the Correctional Services Healthcare Conference, Melbourne, Australia.

Hancock, K., Shepherd, C., Lawrence, D., \& Zubrick, S. (2013). Student attendance and educational outcomes: Every day counts. Canberra: Department of Education, Employment and Workplace Relations.

Hampton, R., \& Toombs, M. (2013). Culture, identity and indigenous Australian people. In R. Hampton \& M. Toombs (Eds.), Indigenous Australians and health: The wombat in the room (pp. 3-23). South Melbourne: Oxford University Press.

Hopkins, S. (2015). Ghosts in the machine: Incarcerated students and the Digital University. Australian Universities Review, 57(2), 46-53.

Hopkins, S., \& Farley, H. (2015). e-learning incarcerated: Prison education and digital inclusion. The International Journal of Humanities Education, 13(2), 37-45.

Hunter, B.H. (2001). Factors underlying Indigenous arrest rates. Sydney: NSW Bureau of Crime Statistics and Research. Retrieved from: http://www.lawlink.nsw.gov.au/lawlink/bocsar/ll_ bocsar.nsf/vwFiles/R52.pdf

Indigenous Higher Education Advisory Council. (2006). Improving indigenous outcomes and enhancing indigenous culture and knowledge in Australian higher education. Canberra: Minister for Education, Science and Training.

Jeroschewski, A., Levisse, A., Salazar, L., Tesoriero, R., \& Ying, S. (2013). Connecting Southeast Asia through broadband. In B. Das (Ed.), Enhancing ASEAN's connectivity (pp. 72-90). Singapore: Institute of Southeast Asia Studies.

Levin, H. M. (2009). 2008 AERA distinguished lecture: The economic payoff to investing in educational justice. Educational Researcher, 38(1), 5-20.

Mackay, A. (2015). Overcrowding in Australian prisons: The human rights implications. Precedent, 128(May/June), 37-41.

Malcolm, I. G., \& Königsberg, P. (2007). Bridging the language gap in education. In G. Leitner \& I. G. Malcolm (Eds.), The habitat of Australia's aboriginal languages: Past, present and future (pp. 267-297). Berlin: Mouton de Gruyter.

Martin, L. (2015). WA aboriginal children 53 times more likely to be jailed than peers, Amnesty report reveals. Retrieved from: http://www.abc.net.au/news/2015-06-11/wa-chief-justiceslams-high-rate-of-aboriginal-incarceration/6538006

Memmott, P., Stacy, R., Chambers, C., \& Keys, C. (2001). Violence in indigenous communities. Barton: Crime Prevention Branch, Commonwealth Attorney-General's Department.

Miller, C. (2007). Education and training for indigenous people in prisons. In S. Dawe (Ed.), Vocational education and training for adult prisoners and offenders in Australia: Research readings (pp. 204-234). Adelaide: NCVER.

Morgan, N. (2014). 2013/2014 Annual report of the Inspector of Custodial Services. Perth: Office of the Inspector of Custodial Services.

Pechenkina, E., \& Anderson, I. (2011). Background paper on indigenous Australian higher education: Trends, initiatives and policy implications. Canberra: Department of Education Employment and Workplace Relations. 
Queensland Corrective Services. (2015, August 19). Lotus Glen Correctional Centre. Retrieved from http://www.correctiveservices.qld.gov.au/About_Us/The_Department/Custodial_ Corrections/Lotus_Glen_Correctional_Centre/index.shtml

Salane, F. (2008). Distance education in prisons: An educational right or a privilege. Trans. Distances et savoirs, 6(3), 413-436.

Taillier, S. (2015). Aboriginal incarceration rates at crisis point, says social justice commissioner Mick Gooda. Retrieved from: http://www.abc.net.au/news/2015-04-09/aboriginalincarceration-rates-at-crisis-point-mick-gooda/6379206

Torre, M. E., \& Fine, M. (2005). Bar none: Extending affirmative action to higher education in prison. Journal of Social Issues, 61(3), 569-594. doi:10.1111/j.1540-4560.2005.00421.x.

University of Southern Queensland. (2012). Promise Fulfilled: USQ Strategic Plan 2013-2015. Toowoomba: University of Southern Queensland.

Wang, F., \& Hannafin, M. J. (2005). Design-based research and technology-enhanced learning environments. Educational Technology Research \& Development, 53(4), 5-23.

Warner, K. (1998). The "prisoners are people" perspective - and the problems of promoting learning where this outlook is rejected. Journal of Correctional Education, 49(3), 118-132.

Weatherburn, D., Snowball, L., \& Hunter, B. H. (2006). Economic and social factors underpinning indigenous contact with the justice system: Results from the 2002 NATSISS survey, The. BOCSAR NSW Crime and Justice Bulletins, p. 16.

Yunkaporta, T. K. (2009). An overview of Aboriginal pedagogy models and a proposal for a workable common-ground framework. Doctoral Dissertation, James Cook University, 2009. Retrieved from http://researchonline.jcu.edu.au/10974/

Zubrick, S., Silburn, S., Lawrence, D., Mitrou, F., Dalby, R., Blair, E., Griffin, J., Milroy, H., De Maio, J., Cox, A., \& Li, J. (2005). The Western Australian aboriginal child health survey: The social and emotional wellbeing of aboriginal children and young people. Perth: Curtin University of Technology and Telethon Institute for Child Health Research.

Open Access This chapter is licensed under the terms of the Creative Commons Attribution 4.0 International License (http://creativecommons.org/licenses/by/4.0/), which permits use, sharing, adaptation, distribution and reproduction in any medium or format, as long as you give appropriate credit to the original author(s) and the source, provide a link to the Creative Commons license and indicate if changes were made.

The images or other third party material in this chapter are included in the chapter's Creative Commons license, unless indicated otherwise in a credit line to the material. If material is not included in the chapter's Creative Commons license and your intended use is not permitted by statutory regulation or exceeds the permitted use, you will need to obtain permission directly from the copyright holder.

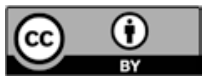

